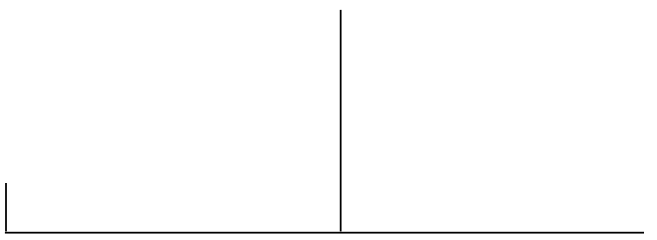

Rev. Latinoam. Psicopat. Fund., São Paulo, v. 15, n. 3, p. 612-614, setembro 2012

A anatomia da melancolia

Robert Burton

Curitiba: Editora UFPR, 2011, 266 págs.

\title{
Experto crede Roberto
}

Roberto Kirschbaum

2011 foi um ano doce para a melancolia no Brasil. Com o empurrãozinho do filme dinamarquês homônimo, o termo foi amplamente difundido pela mídia. Artigos, não somente sobre o filme, mas sobre a própria melancolia, foram publicados em revistas e jornais de grande circulação. Assim, a melancolia, que a partir da segunda metade do século passado foi praticamente substituída nos vocabulários médico e popular pelo termo nada adequado depressão, faz sua reestreia em nosso repertório.

Neste solo fértil e com timing perfeito é publicada no Brasil, ainda que tardiamente em relação à edição original inglesa de 1621 , a primeira tradução para a língua portuguesa da obraprima de Robert Burton: A anatomia da melancolia, com subtítulo "O que é, com todas as suas espécies, causas, sintomas, prognósticos e diversas curas. Em três partições, com diversas Seções, membros e subseções. Filosófica, Medicinal e Historicamente aberta e dissecada por Demócrito Junior". Burton, acadêmico inglês, teólogo, vigário e bibliotecário na Universidade de Oxford, utiliza-se do nome Demócrito Junior mais do que como um simples pseudônimo para escrever a 
partir da sua própria melancolia, mas como forma de se declarar herdeiro e sucessor de Demócrito de Abdera, o "filósofo que ri”, contemporâneo do mesmo Hipócrates reverenciado no juramento médico até os dias de hoje. Conta-nos Burton no longo e cativante prefácio satírico que, a pedido dos preocupados abderitas, que consideravam Demócrito louco, Hipócrates foi visitá-lo. Encontrou-o compenetrado, dissecando pequenos animais em busca da sede da atra bilis, bílis negra, ou melancolia, e escrevendo um livro sobre melancolia e loucura. Depois da conversa que tiveram, Hipócrates voltou à cidade convencido de que loucos estavam os abderitas, e que Demócrito é que era o são. O livro de Demócrito Abderita teria se perdido. Demócrito Junior se propõe então a escrever um novo livro, à altura do mestre. Suas credenciais? Melancólico ele mesmo, afirma: "aquilo que os outros lêem ou escutam, senti e pratiquei em mim mesmo; eles ganham conhecimento nos livros e eu na melancolia. Experto crede Roberto [Crê em Robert, ele é expert]."

Mas a quem interessaria hoje esse livro tão antigo? Burton nos daria uma resposta curta: "És tu o assunto deste meu discurso". O livro trata do ser humano, e a todos os seres humanos pode interessar. Aos historiadores, há referências e citações históricas à exaustão. É pleno de jogos literários e explorações linguísticas, tendo na literatura e na arte um grande exército de admiradores: Anthony Burgess, John Keats, Jorge Luis Borges, Moacyr Scliar, para citar apenas alguns. A grande obra de Klibansky, Panofsky e Saxl, "Saturno e Melancolia - Estudos na História da Filosofia Natural, Religião e Arte”, de 1964, traz a foto do túmulo de Robert Burton na contracapa.

Com os clínicos, estudiosos da psique e da história da psicopatologia, o livro compartilha muito do que já havia sido pensado e produzido sobre a melancolia no século XVII, o que não era pouco. Poderia se dizer que a melancolia não existe mais como doença oficialmente reconhecida. Neste sentido a obra pode ser ponto de partida para reflexões muito atuais, especialmente a questão da crescente medicalização da sociedade em detrimento da subjetividade. No prefácio a esta edição brasileira, Manoel Tosta Berlinck traça a evolução da compreensão e interpretação da melancolia desde Aristóteles, passando por Burton, mais recentemente Freud, que a considera uma neurose narcísica, e chegando por fim à interpretação atual e empobrecida do termo que, sendo rebatizado de depressão ou transtorno afetivo bipolar, reduz uma "formação repetitiva e padronizada do inconsciente, extremamente duradoura e resistente à mudança, manifestando-se de forma sintomática" a apenas um dos possíveis estados desta doença que pode e deve ser suprimido quimicamente. Prosseguindo, Berlinck aborda as descobertas de Freud e Karl Abraham que permitem compreender o ser humano como espécie melancólica, e a melancolia, pelo menos numa forma benigna, não como doença, curável, mas como condição humana da qual se pode até tirar proveito. 


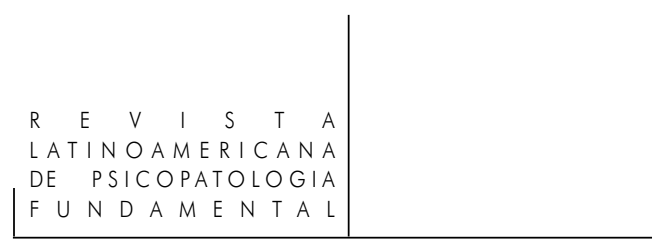

O trabalho de tradução foi realizado com esmero. Guilherme Gontijo Flores consultou algumas edições em língua inglesa e outras em línguas neolatinas. Procurou dar ao texto um estilo comparável ao de Burton, por um lado "erudito na linguagem", por outro "inegavelmente leve e, na medida do possível, bastante oralizado e popular na sua língua". Poderia se dizer que o autor não escreve, mas livre-associa, tentando elaborar sua melancolia. A experiência da leitura se assemelha assim a uma conversa com um interlocutor bastante erudito mas ao mesmo tempo jovial, espontâneo e coloquial.

\section{Referências}

BuRTon, R. A anatomia da melancolia. Trad. Guilherme Gontijo Flores. Prefácio Manoel Tosta Berlinck. Curitiba: Editora UFPR, 2011. V. I.

Burton, R. (1621, ed. de 1632). Anatomia de la melancolia. Prefácio de Jean Starobinski. Madrid: Associación Española de Neuropsiquiatría, 2003.

Klibansky, R.; Panofsky, E.; Saxt, F. (1964). Saturn and Melancholy. Studies in the History of Natural Philosophy, Religion and Art. Nendeln/Liechtenstein: Kraus Reprint, 1979.

\section{ROBERTO KIRSChBAUM}

Psicólogo e psicanalista; Mestrando pelo Programa de Estudos Pós-Graduados em Psicologia Clínica da Pontifícia Universidade Católica de São Paulo - PUC-SP (São Paulo, SP, Br) sob orientação do Prof. Dr. Manoel Tosta Berlinck; bolsista do Conselho Nacional de Desenvolvimento Científico e Tecnológico - CNPq (Brasília, DF, Br)

Rua Veríssimo Glória, 165

01251-140 São Paulo, SP, Br

Fone: (11) 2935-8310

e-mail: robertokir@gmail.com

Rev. Latinoam. Psicopat. Fund., São Paulo, v. 15, n. 3, p. 612-614, setembro 2012 